\title{
Is post-commencement finance proving to be the thorn in the side of business rescue proceedings under the 2008 Companies Act?
}

\author{
Juanitta Calitz \\ Bluris LLB LLM LLD \\ Associate Professor of Mercantile Law, University of Johannesburg \\ Giles Freebody \\ $L L B$ LLM \\ LLM Student, University of Johannesburg
}

\begin{abstract}
OPSOMMING
Is na-aanvangsfinansiering die doring in die vlees van ondernemingsreddingsverrigtinge ingevolge die 2008 Maatskappywet?

Ondernemingsredding word toenemend as 'n gewilde en belangrike punt op die wetgewende agenda van lande wêreldwyd beskou. In Suid- Afrika het die Maatskappywet 71 van 2008 (die Wet) wat op 1 Mei 2011 in werking getree het, geregtelike bestuur vervang met 'n ondernemingsreddingmodel wat onder andere die rehabilitasie van 'n maatskappy in finansiële nood as doelstelling het. Een van die sleutelfaktore van 'n suksesvolle ondernemingsreddingproses is die verkryging van na aanvangsfinansiering. Die onderhawige artikel bevat 'n bespreking van die spesifieke tekortkominge van die ondernemingsreddingmodel wat 'n nadelige effek het op die vekryging van na -aanvangsfinansiering in die praktyk. Aandag word ook geskenk aan ondernemingsreddingsverrigtinge, na -aanvangsfinansiering in die algemeen en die rangorde van die eise van skuldeisers wat sogenaamde na -aanvangsfinansiering verleen. Daar word ook gekyk na die benadering wat deur die Verenigde State van Amerika in hoofstuk 11 van die Amerikaanse 'Bankruptcy Code', asook ander internasionale instrumente, gevolg word. Die outeurs doen dan ten slotte aan die hand dat ondernemingsredding as model slegs kan slaag indien daar 'n paradigma skuif plaasvind wat wat tot 'n meer skuldenaarvriendelike milieu tot gevolg sal hê en sodoende sal verseker dat na aanvangsfinansiering meer vrylik beskikbaar sal wees.
\end{abstract}

\footnotetext{
* This article is partly based on Freebody Is post-commencement finance proving to be the thorn in the side of business rescue proceedings under the Companies Act of 2008? (LLM dissertation UJ 2014).
} 


\section{Introduction}

The Chinese use two brush strokes to write the word 'crisis'. One brush stroke stands for danger; the other for opportunity. In a crisis, be aware of the danger - but recognize the opportunity.

(J. F. Kennedy, Speech in Indianapolis, Indiana, 12 April 1959) ${ }^{1}$

Corporate rescue has become an increasingly popular topic on the legislative agenda of many countries, and has long been a focus of global interest. The Companies Act 71 of 2008, ${ }^{2}$ which contains Chapter 6 entitled 'Business rescue and compromise with creditors', introduced a new corporate rescue regime into the South African commercial law landscape. ${ }^{3}$ This new approach was welcomed as it was generally accepted that the process of judicial management was a failure in practice. ${ }^{4}$ The purpose of this particular chapter in the Act is to provide the opportunity to companies that are financially distressed to reorganise and restructure themselves in order to have the best possible chance of returning to a position of solvency while having regard to the rights and interests of all stakeholders. ${ }^{5}$

Where the option of rescuing a business is available, many jurisdictions have now recognised that any going concern strategy requires a means of financing the business until such time as the rescue plan can be successfully devised and implemented. ${ }^{6}$ It logically follows that one of the most important factors to business rescue proceedings in bringing about a successful rehabilitation is thus that of postcommencement finance. It has also been stated that postcommencement finance 'is potentially one of the most important, and most problematic, aspects of a successful business rescue model'. 7 A recent study done in the United States (US) also acknowledged that '[a]s a general matter, the Commissioners recognized the need for a robust,

1 Olivares-Caminal Phoenix Operations in the Pre-packaged Administration: A Rescue for the Company or a Trap for the Creditors? (LLM Dissertation QMUL 2013).

2 Hereinafter the '2008 Companies Act' or 'the Act'.

3 The Act came into effect in May 2011.

4 Burdette 'Some initial thoughts on the development of a modern and effective business rescue model for South Africa (Part 1)' 2004 SA Merc LJ 241 (hereinafter Burdette Part 1); Le Roux Hotel Management (Pty) Ltd v E Rand (Pty) Ltd 20012 SA 727 (C).

5 Rushworth 'A critical analysis of the business rescue regime in the Companies Act 71 of 2008' 2010 Acta Juridica 375; s 7(k) of the 2008 Companies Act.

6 Sarra 'Financing Insolvency Restructurings in the Wake of the Financial Crisis: Stalking Horses, Rogue White Knights and Circling Vultures' 2011 Penn State International Law Review 582. Pretorius \& Du Preez 'Constraints on decision making regarding post-commencement finance in business rescue' 2013 South African Journal of Entrepreneurship and Small Business Management 170.

7 Burdette 'The development of a modern and effective business rescue model for South Africa: Pre consultation working document' (2004) 51; see also Prins Priority issues in business rescue (LLM dissertation UCT 2015) 3-5. 
competitive post-petition financing market and the value it provides to distressed companies'. 8

There have also been a number of cases where the courts have emphasised the importance of the availability of post-commencement financing in order to meet the requirement that the court must be satisfied that there is a reasonable prospect of rescuing the business as contained in section 131(4) of the Companies Act. ${ }^{9}$ South Africa seems to lag behind in the 'corporate rescue' realm in terms of having a debtorfriendly rescue culture; this may well be because of the relatively new status of the legislation or specific challenges associated with an emerging market economy. ${ }^{10}$

It should be noted that the post-commencement financing of financially distressed companies is a challenging and complex subject and this paper will not attempt to deal with all the legal aspects and principles related to this process in detail but, instead, will aim to identify some of the shortcomings as well as stimulate some discussion of the next step scholars need to take in understanding the role of postcommencement finance in the business rescue environment. Business rescue proceedings, post-commencement finance and the ranking of claims in general will also be discussed. A brief comparison will be drawn against the US rescue administration procedure, which is contained in Chapter 11 of the Code, ${ }^{11}$ as well as the guidance provisions that have been issued by the United Nations Commission on International Trade Law (UNCITRAL) and the World Bank in order to determine what

8 Goffman, McDermott, Panagakis \& Turetsky 'Overview of ABI Commission Report and Recommendation on the Reform of Chapter 11 of the Bankruptcy Code' (2014) Skadden 75 available from https://www. skadden.com/sites/default/files/publications/Overview_of_ABI_Commission _Report_and_Recommendation_on_the_Reform_of_Chapter_11_of_the_Ba nkruptcy_Code.pdf (accessed 2016-06-30).

9 Loubser 'Post -commencement financing and the ranking of claims - A South African perspective' in Perry (ed) European Insolvency Law: Current Issues and Prospects for Reform (2014) 31; see inter alia AG Petzetakis International Holdings Ltd $v$ Petzetakis Africa (Pty) Ltd (Marley Pipe Systems (Pty) Ltd Intervening) 20125 SA 515 (GSJ) par 29; Southern Palace Investments 265 (Pty) Ltd v Midnight Storm Investments 386 (Pty) Ltd (15155/ 2011) [2011] ZAWCHC 442 (25 November 2011); 20122 SA 423 (WCC); Oakdene Square Properties (Pty) Ltd and Others $v$ Farm Bothasfontein (Kyalami) (Pty) Ltd and Others 20134 SA 539 (SCA) par 33; Newcity Group (Pty) Ltd v Pellow, China Construction Bank Corporation Johannesburg Branch $v$ Crystal Lagoon Investments 53 (Pty) Ltd (12/45437, 16566/12) [2013] ZAGPJHC 54 (28 March 2013).

10 In Swart $v$ Beagles Run Investments 25 (Pty) Ltd (Four Creditors Intervening) 20115 SA 422 (GNP) 28, Makgoba J stated that 'where an application for business rescue ... entails the weighing-up of the interests of the creditors and the company the interests of the creditors should carry the day'.

11 The Bankruptcy Code of 1978 came about as a result of the Report of the Commission on the Bankruptcy Laws of the United States HR Doc no 137 93d Congress session 1973. The Bankruptcy Reform Act of 1978 was most recently amended by the Bankruptcy Abuse Prevention and Consumer Protection Act (BAPCPA) of 2005. 
prerequisites are necessary in a system to ensure that successful turnaround financing is secured for distressed companies. Lastly, some suggestions are made to improve the current position in South Africa as well as for future research activity.

\section{Business Rescue in South Africa: A Brief Discussion}

The globalisation of trade and business activities is having an impact on many areas of our law and the global economic crisis has had an effect on companies worldwide. ${ }^{12}$ Wood describes liquidation as the 'guillotining of a company' and considers it to be a drastic measure. ${ }^{13}$ Once a liquidation order is granted, there are certain consequences that ensue such as the demise of the corporate entity, loss of employment for many, as well as 'an unsatisfactory pro rata share in the residue for unsecured creditors, and the abandonment of claims when such are not proved'. ${ }^{14}$ Due to such results, it is appropriate to have legislation that provides other options in situations of business turmoil.

The business rescue procedure attempts to provide temporary measures that aid in the rehabilitation of a company. For the duration of such a rescue, the company's management will be placed under the supervision of a business rescue practitioner and will have a moratorium placed on all claims against the company on behalf of the creditors. ${ }^{15}$ In the case of Merchant West Working Capital Solutions (Pty) Ltd $v$ Advanced Technologies and Engineering Company (Pty) Ltd ${ }^{16}$ Kgomo J commented that:

business rescue is also a system that is aimed or geared at temporarily protecting a company against the claims of creditors so that its business can thereafter be disposed of (if concern could not be saved) for maximum value as a going concern in order to give creditors and shareholders a better return than they would have received had the company been liquidated. ${ }^{17}$

12 Du Preez The status of post-commencement finance for business rescue in South Africa (MBA dissertation 2012 Gordon Institute of Business Science, UP) 1 .

13 Wood Principles of International Insolvency Law (2007) 31.

14 Bradstreet 'The new business rescue: will creditors sink or swim?' 2011 SALJ 352.

15 Bradstreet 'The leak in the lifeboat: Inadequate regulation of business rescue practitioners may adversely affect lenders' willingness and the growth of the economy' 2010 SA Merc LJ 195; s 133 of 2008 Companies Act.

16 Merchant West Working Capital Solutions (Pty) Ltd $v$ Advanced Technologies and Engineering Company (Pty) Ltd (13/12406) [2013] ZAGPJHC 109 (10 May 2013).

17 Idem par 4; see also s 133 of 2008 Companies Act. 
There are two ways in which such proceedings can be entered into, namely, by a voluntary resolution by the board of directors, or by an application to court by an 'affected' person. ${ }^{18}$ The actual bodywork of the rescue process will be assembled in the form of a 'rescue plan' drafted by the business rescue practitioner in terms of the Act. ${ }^{19}$ This plan deals with all of the company's affairs, assets, liabilities and other relevant areas relating to the business, and attempts to strategise a way in which these elements can be restructured in order to maximise the chances of the distressed company returning to solvency. ${ }^{20}$ There have been various high-profile cases in which large South African companies have entered into business rescue proceedings. These instances have brought the proceedings and their results to the attention of the public through the media hype surrounding them. ${ }^{21}$

In any corporate rescue regime it is clear that financial support is required from the surrounding commercial domain in order to enable the rescue to take place. As noted by Du Preez, during times of economic downturn such financing is more difficult to come by as investors are wary of the risks involved in placing money in what is essentially, a failing entity. ${ }^{22}$ Ironically, when financing is needed most in order to secure a turnaround for the business in question, it is often unavailable, or the creditors themselves are financially troubled. Thus, one of the most important factors of a corporate rescue effort involves obtaining additional finance to meet temporary trade obligations, such as working capital requirements, and covering the rescue/restructuring costs in order for a company to recover swiftly from its temporary liquidity challenges. In addition, the availability of new finance is also vital for the approval of a business rescue plan. ${ }^{23}$

18 Davis et al Companies and other Business Structures in South Africa (2011) 165-167; ss 129 \& 131 of the 2008 Companies Act.

19 Part D of Chapter 6 deals with the development and approval of a business rescue plan.

20 S 128(1)(b) of the Act.

21 See the example of Sanyati where the ineffective post-commencement financing scheme led to the tragic demise of the business. Sanyati was building roads for the South African government and subsequently the government accrued a debt of R79 million to the company. The company went into business rescue but was in desperate need of financing to complete its existing contracts. After the President intervened, some payments were made to the company but most other suppliers, by then, had cancelled their contracts due to non-payment. The company consequently terminated the business rescue proceedings and went into liquidation. See Loubser 'Post-commencement financing and the ranking of claims - A South African perspective' in Perry (ed) supra n 9 at 31.

22 Du Preez 6

23 Pretorius \& Du Preez 2013 South African Journal of Entrepreneurship and Small Business Management 170; Kunst et al Meskin, Insolvency Law and its Operation in Winding-up (loose-leaf edition) (2014 updated version, LexisNexis) par 18.8.2.3. 


\section{Post-commencement Finance - A Current South African Perspective}

It can be extremely difficult for a company to secure funding when it is the subject of business rescue proceedings; this is due to the fact that lenders have the valid concern that they may not see a return on their investment. ${ }^{24}$ Where the classic common pool problem presents itself, creditors will generally prefer the relative certainty afforded by insolvency proceedings which usually facilitate normative objectives that include the orderly and equitable distribution of a debtor's assets where they are insufficient to meet the claims of all his creditors. ${ }^{25}$ Van der Linde also mentions the following:

Policy considerations in favour of a priority for post-commencement financing have to be balanced against established principles including the pari passu rule, the vested rights principle, the ideal of upholding commercial bargains and, in regard to secured claims, the prior in tempore maxim. ${ }^{26}$

In order to sustain the business as a going concern, there are certain business activities that will require funding, such as 'goods and services from suppliers, labour costs, insurance, rent, maintenance of contracts and other operating expenses, along with the cost of maintaining the value of assets' and thus it is imperative to obtain a source of finance as soon as possible. ${ }^{27}$ It must be emphasised that post-commencement financing extends from short-term goals to that of the long-term strategy that will be implemented in trying to obtain a successful turnaround. ${ }^{28}$

In order to deal with the difficulty of obtaining such financing, Chapter 6 provides, under section 135, mechanisms through which such financing becomes more attractive to the financier. ${ }^{29}$ In short, this is done by conferring priority or allowing the company to use its assets as security for such loans. 30

The nature and extent of post-commencement financing is detailed in section 135 of the Companies Act as follows:

24 Davis supra $\mathrm{n} 18$ at 170.

25 Sarra 2011 Penn State International Law Review 582. See Kirshner 'Design flaws in the Bankruptcy Regime: Lessons from the U.K. for preventing a resurgent creditors' race in the U.S.' 2014 University of Pennsylvania Journal of Business Law 530.

26 Van der Linde 'Priority issues in post-commencement financing - a view from South Africa' in Wessels \& Omar (eds) The Intersection of Insolvency and Company Laws (2008) - Papers from the INSOL Europe Academic Forum Annual conference Barcelona, Spain, 1-2 October 200841.

27 Pretorius \& Rosslyn-Smith 'Expectations of a business rescue plan: international directives for Chapter 6 implementation' 2014 Southern African Business Review 132.

28 UNCITRAL UNCITRAL Legislative Guide on Insolvency Law (2005) 113 available from http://www.uncitral.org/pdf/english/texts/insolven/05-80722 Ebook.pdf (accessed 2014-10-08).

29 Sharrock et al Hockly's Insolvency Law (2012) 289

30 Davis supra 18 at 170. 
(1) To the extent that any remuneration, reimbursement for expenses or other amount of money relating to employment becomes due and payable by a company to an employee during the company's business rescue proceedings, but is not paid to the employee -

(a) the money is regarded to be post-commencement financing; and

(b) will be paid in the order of preference set out in subsection (3)(a).

(2) During its business rescue proceedings, the company may obtain financing other than as contemplated is subsection (1), and any such financing -

(a) may be secured to the lender by utilizing any asset of the company to the extent that it is not otherwise encumbered; and

(b) will be paid in the order of preference set out in subsection (3)(b).

(3) After payment of the practitioner's remuneration and expenses referred to in section 143, and other claims arising out of the costs of the business rescue proceedings, all claims contemplated -

(a) in subsection (1) will be treated equally, but will have preference over-

(i) all claims contemplated in subsection (2), irrespective of whether or not they are secured; and

(ii) all unsecured claims against the company; or

(b) in subsection (2) will have preference in the order in which they were incurred over all unsecured claims against the company.

(4) If business rescue proceedings are superseded by a liquidation order, the preference conferred in terms of this section will remain in force, except to the extent of any claims arising out of the costs of liquidation.

The ranking of creditors' claims are also important for purposes of comprehending why investors are sometimes reluctant to invest in companies that are subject to rescue proceedings. In summary these claims rank as follows:

(1) The business rescue practitioner's remuneration and costs arising from business rescue proceedings; 31

(2) All post-commencement finance claims related to employment once business rescue has commenced but which have not yet been paid; ${ }^{32}$

(3) Claims for post-commencement loans obtained during business rescue, firstly secured claims in the order in which they were incurred; 33

(4) All other unsecured claims against the company. ${ }^{34}$

If the business rescue proceedings are superseded by a liquidation order, the preferences mentioned above continue to apply, but the claims would rank below the costs of liquidation. ${ }^{35}$

There has been considerable debate surrounding these rankings, in particular regarding the position of lenders who attained their security prior to the business rescue proceedings. ${ }^{36}$ In the Merchant West case, Kgomo J stated that the claim belonging to pre-business rescue secured

$1 \quad$ S 135(3)) (as per s 143); Murgatroyd $v$ Van den Heever [2014] JOL 32250 (GJ).

32 S 135(1); s 135(3)(a). The employees' claims rank equally to and have preference over the claims of creditors.

33 Ss $135(3)$ (a) \& $135(2)$.

34 S 135(3)(b).

35 S $135(4)$

36 Du Preez 14 
creditors will now rank below those creditors who have supplied funding to the distressed entity during business rescue proceedings (i.e. postcommencement financiers). ${ }^{37}$ As correctly pointed out by Prins, the ranking set out by Kgomo J specifically refers to an earlier publication by Stein and uses a verbatim copy of the ranking as suggested by the present authors. ${ }^{38}$ Subsequently, in Redpath Mining South Africa $v$ Marsden, ${ }^{39}$ Kgomo J confirmed his previous dicta by once again stating that the ranking is as listed in the judgment handed down in the Merchant West case. ${ }^{40}$

Despite these judgments declaring the ranking of creditor claims, the particular cases' focal points were not related to the ranking of claims and thus it is submitted that both comments by the same judge should be considered to be obiter.

In section 134(3), the legislature deals with the position of secured creditors and states that:

If, during a company's business rescue proceedings, the company wishes to dispose of any property over which another person has any security or title interest, the company must:

(a) obtain the prior consent of that other person, unless the proceeds of the disposal would be sufficient to fully discharge the indebtedness protected by that person's security or title interest; and

(b) promptly;

(i) pay to that other person the sale proceeds attributable to that property up to the amount of the company's indebtedness to that other person; or

(ii) provide security for the amount of those proceeds, to the reasonable satisfaction of that other person. ${ }^{41}$

The Act then proceeds in section 135(2)(a) to state that financing during business rescue may be secured only by assets not otherwise encumbered. ${ }^{42}$ Van der Linde also states that:

Section 134(3) expressly regulates the rights of secured creditors during business rescue proceedings and makes it clear that if the property is sold, the secured claim must be 'promptly' paid from the proceeds or otherwise (alternative) security for its payment must be provided to the satisfaction of the secured creditor. This principle applies for the entire duration of business rescue proceedings. It is obvious that section 135(3), which sets out the ranking of claims, makes no mention of secured pre-commencement claims.

37 Merchant West case supra $\mathrm{n} 16$ at par 21.

38 See Stein \& Everingham The New Companies Act Unlocked: A Practical Guide (2011) 421, an earlier publication which provided one of the first interpretations of the ranking of creditors' claims under business rescue. See also Prins 8.

39 (18486/2013) [2013] ZAGPJHC 148 (14 June 2013).

40 Idem par 60.

41 Ss 134 (3)(a)-(b); see Kritzinger and Another $v$ Standard Bank of South Africa (3034/2013) [2013] ZAFSHC 215 (19 September 2013) par 30.

$42 \mathrm{~S} 135(2)(\mathrm{a})$. 
In my view this is precisely because these claims are paid separately from the proceeds of the security that no mention is made of them in section $135 .^{43}$

It is therefore clear that the position of pre-commencement secured creditors has clearly been excluded from the section 135 ranking scenario and it is submitted that it was not the intention of the legislature to revise the position or alter the preference of the secured lender during business rescue proceedings. Van der Linde also mentions that the Act clearly states that the post-commencement claims of employees are expressly said to enjoy priority over post-commencement claims, whether secured or not. The express reference to 'whether secured or not' is a clear indication that the legislature wanted to introduce an exception to the general principle of separation between secured and unsecured claims. ${ }^{44}$ Henochsberg also expressly disagrees with the interpretation by Kgomo $\mathrm{J}$ in the Merchant West case, and mentions that this ranking does not seem to be in accordance with the wording of section 135 , since there is no reference in that particular section to claims by pre-commencement secured lenders. ${ }^{45}$

As a result of these recent inferences from case law accompanied by vigorous academic debate, the subject of creditor ranking in terms of business rescue proceedings has the potential of becoming an uncertain and undefined area in our law and creating an additional obstacle to the business rescue practitioner's already difficult task of securing postcommencement finance.

\section{Comparative Overview}

\section{The US 'Debtor in Possession' System}

Due to the lack of literature relating to post-commencement financing in developing countries such as South Africa, it seems necessary to delve into one of the most recognised corporate rescue systems in the world, namely that of the US. A secondary reason for choosing to explore this jurisdiction lies in the fact that when the South African legislature decided that it was necessary to move away from judicial management and develop a corporate rescue procedure, that would be inherently more successful than its predecessor, it was stated that in creating this new and improved reorganisation process 'the provisions of the US Chapter 11 would be considered'. ${ }^{46}$ This was not the first time that it had been suggested that the Bankruptcy Code - as operated in the US - should be

43 Van der Linde 'Company and Insolvency Law Update' 2014 Annual Banking law Update 15. On file with author.

44 Ibid.

45 Delport et al Henochsberg on the Companies Act 71 of 2008 (2011) (Loose-leaf Edition) 478(10)-(12).

46 See Department of Trade and Industry 'South African company law for the 21 st century: guidelines for corporate reform' 2004 Notice 1183 of 2004 GG 2649345. 
considered. ${ }^{47}$ Commentators had often noted that judicial management was dysfunctional and needed to be reworked by paying close attention to the US system. ${ }^{48}$ It has been pointed out that it was a common trend in European countries, during reform of their particular insolvency laws, to give special time and consideration to Chapter 11 and its procedures. $^{49}$

To understand the US Chapter 11 provisions properly, it is essential to look at the origins and rationale behind the Chapter 11 proceedings. ${ }^{50}$ As Martin explains:

The current U.S. bankruptcy system grew directly out of the United States' unique capitalist system, which rewards entrepreneurialism as well as extensive consumer spending. It makes sense that a society in which dollars rule would have a forgiving personal bankruptcy system in order to keep consumer spending high, and an equally forgiving business reorganization system to encourage risk taking and economic growth. Both systems are part of a larger scheme to keep economic players alive and active in the game of capitalism. U.S. bankruptcy systems are among the country's few social programs and they address many of society's ills. Thus, they are broad and form an integral part of the social system from which they sprung. ${ }^{51}$

The main difference between US-style reorganisation and that of most other jurisdictions is that in the US, current management of the failing company normally stays in place with no administrator directly supervising the proceedings. ${ }^{52}$ The historical development of this unique principle originates from the first reorganisations in the railroad industry. At the time that the Munroe Railroad and Banking Company defaulted on its obligations to its lenders, there was no legal framework in place to address this particular business failure, other than the lender's right to foreclose and the court's equitable right to appoint a receiver to take over the debtor's assets. ${ }^{53}$ Due to a piecemeal sale of the debtor's assets,

47 Bankruptcy Reform Act of 1978.

48 Rajak \& Henning 'Business rescue for South Africa' 1999 SALJ 262.

49 Omar 'Four models for rescue: convergence or divergence in European insolvency law? (Part 2)' 2007 International Company and Commercial Law Review 179; Loubser 'Tilting windmills? The quest for an effective corporate rescue procedure in South African law' 2013 SA Merc LJ 439.

50 Martin 'The Role of History and Culture in Developing Bankruptcy and Insolvency Systems: The Perils of Legal Transplantation' 2005 Boston College International and Comparative Law Review 32.

51 Ibid.

52 Ibid. See also Metzger \& Bufford 'Exporting United States Bankruptcy Law: The Hungarian Experience' 1993 California Bankruptcy Journal 153; and Tabb 'The History of the Bankruptcy Laws in the United States' 1995 American Bankruptcy Institute Law Review 18-23.

53 Martin 2005 Boston College International and Comparative Law Review 32; Skeel Debt's Dominion (2001) 57. See also Stuart 'Coming Through in a Crisis: How Chapter 11 and the Debt Restructuring Industry are Helping to Revive the U.S. Economy' 2012 Journal of Applied Corporate Finance 23-35; Goren 'Chip Away at the Stone: The Validity of Pre-Bankruptcy Clauses Contracting around Section 363 of the Bankruptcy Code' 2006/07 New York Law School Law Review 1078-1104. 
potentially resulting in an economic and social catastrophe, the court merged these two legal concepts and ordered that the lender sell the assets as a going-concern sale, rather than piecemeal. This innovation led to a new way of looking at reorganisation and value and subsequently acted as the precursor to the current Chapter 11 system. ${ }^{54}$ Years later, the Act of 1978 introduced Chapter 11 reorganisation; the result of years of development in the US. ${ }^{55}$

The main aim of Chapter 11 is to avoid the complete collapse of an ailing business by providing financial restructuring that is binding on all parties. ${ }^{56}$ During a rescue attempt, a firm enjoys temporary relief from its creditors' claims (similar to the moratorium created in South Africa), so that while still in business, the existing management can examine its current business model and attempt to reorganise it in a way that will bring about a successful resurrection of the said business. ${ }^{57}$ The statutory goal of a Chapter 11 proceeding is the preparation and confirmation of a reorganisation plan. ${ }^{58}$

After the filing of a chapter 11 petition the management of the company will normally remain in control of the debtor's affairs and continue with normal business activities such as making decisions regarding both the debtor's business and its reorganisational options.. ${ }^{59}$

Notably section 1107 of the Code authorises the debtor in possession to, among other things, exercise all 'the rights ... and powers, and [requires it to] perform all the functions and duties ... of a trustee serving in a case under this chapter', with only minor exceptions that do not detract from the central role of the debtor in possession. ${ }^{60}$ Although there is no new addition to the management of the failing entity, these proceedings are subject to judicial oversight and there are exceptional

54 Martin 2005 Boston College International and Comparative Law Review 32; Spannaus "A Short History of "Chapter 11": Model for a Bankrupt Economy Executive' 2002 Intelligence Review 19.

55 Loubser 2013 SA Merc LJ 441. As is known, in the US the laws are divided into state law (applying only to that specific state) and federal law, which is a nationwide ruling. See also Ferriell \& Janger Understanding Bankruptcy (2013) 5.

56 Ferriell \& Janger 4.

57 Goren 2006/07 New York Law School Law Review 1090.

5811 US Code s 1121. The debtor, other than a small business debtor, has a 120-day period during which it has an exclusive right to file a plan. This period may be extended or reduced by the court. But in no event may the exclusivity period, including all extensions, be longer than eighteen months.

59 'Management displacement' in favour of an impartial supervisor or trustee only takes place in extraordinary cases where matters such as fraud, dishonesty or gross mismanagement are involved. See also American Bankruptcy Institute (ABI) 'Commission to Study the Reform of Chapter 11 2012-2014 Final Report and Recommendations' (hereinafter ABI 'Final Report and Recommendations') available from http://digitalcommons. law.umaryland.edu/cgi/viewcontent.cgi? article $=1096 \&$ context $=$ books (accessed 2016-06-30).

6011 USC s 1107; Du Preez 25; ABI 'Final Report and Recommendations’ 22. 
circumstances in which an administrator will replace the management team, for instance in the case of fraud or gross mismanagement. ${ }^{61}$

It must be noted that the US has a debtor-friendly system which essentially entails that the legislation provides companies with protection from creditors in times of uncertainty. In turn, this allows for the best possible chance at a return to solvency. ${ }^{62}$ In a recent study done by the American Bankruptcy Institute (ABI) on the possible reform of Chapter 11 , the following recommendation was included:

Thus, on balance, the Commission concluded that the potential value of a mandatory trustee-like actor was significantly outweighed by the potential disruption, costs, and inefficiencies associated with the displacement of the debtor's management. Accordingly, the Commission recommended retention of the debtor in possession model. ${ }^{63}$

\section{DIP Financing}

Special provisions to deal with corporate restructuring and so called 'debtor-in-possession (DIP)' financing or post-petition financing is a common feature introduced by the 1978 Code. Section 364 of the Code generally governs a debtor in possession's request to obtain post-petition financing and is structured in part to incentivise lenders to extend credit to a company in bankruptcy by providing special creditor rights to postpetition loans. ${ }^{64}$ DIP financing is one of the most vital instruments to enable 'the DIP to provide current or new lenders the first priority claim on the finances (i.e. right of repayment priority) through the acquisition of financing and loans on favorable terms for the company'. ${ }^{65}$ As a practical matter, DIP loans often offer attractive interest rates at relatively low risk, and the DIP creditor often has substantial control over the bankruptcy process. ${ }^{66}$

A pre-petition secured creditor that intends to provide post-petition financing may obtain a lien against collateral (real or personal property) acquired by the debtor in possession after the commencement of the

61 Gaur 'Post-petition financing in corporate insolvency proceedings' 2012 Taxmann's SEBI \& Corporate Laws Journal 19.

62 See generally Couwenberg \& De Jong 'It takes two to tango: An empirical tale of distressed firms and assisting banks' 2006 International Review of Law and Economics 429.

63 ABI 'Commission to Study the Reform of Chapter 11 2012-2014 Final Report and Recommendations' (hereinafter ABI 'Chapter 11 Commission Report') 22 available from http://digitalcommons.law.umaryland.edu/cgi/ viewcontent. cgi? article $=1096 \&$ context $=$ books $($ accessed 2016-06-30)

64 US Bankruptcy Code, 11 USC s 364; see also ABI 'Chapter 11 Commission Report' 74.

65 Du Preez 26.

66 Mindlin 'Comparative analysis of Chapter 6 of the South African Companies Act, no. 71 of 2008 (Business Rescue Proceedings)' presentation to the Company Law Symposium, Johannesburg South Africa, 1 March 12013. See also Zdunkewicz 'Recent Trends and Developments in DIP Financing' 2014 SRR Guest Article available from http://www.srr.com/assets/pdf/ recent-trends-and-developments-dip-financing.pdf (accessed 2016-06-30). 
case and is referred to as 'cross-collateralization' ${ }^{67}$ If a pre-petition creditor doesn't demonstrate a significant commitment to provide postpetition credit as opposed to merely strengthening its pre-petition claim, a Bankruptcy Court will generally not approve such credit. ${ }^{68}$

Section 364 of the Code sets out four different financing options, each of which involves a progressively greater measure of protection for such lenders: 69

(1) Section 364(a) hands the debtor an automatic right (unless the court orders otherwise) to incur unsecured debt as a first-priority administration expense (top-ranking claim) or as secured debt, and to acquire unsecured obligations in the ordinary course of business. ${ }^{70}$. The DIP can thus seek to obtain credit as an 'administrative expense'.

(2) A post-petition creditor may also provide an unsecured loan outside of the ordinary course of business after notice and a hearing. ${ }^{71}$

(3) If such financing is not obtainable, the following option would be that the DIP loan can be given 'super-priority' over other administrative expenses, secured against any unencumbered property, or secured by a junior lien on property that is already encumbered. ${ }^{72}$

(4) As a final credit enhancement option a bankruptcy court can grant the DIP lender a senior or equal lien on encumbered property of the estate (so-called 'priming lien') so long as there is 'adequate protection' ${ }^{73}$

In section 364(d), it is stated that a 'super-priority' status will only be placed on pre-petitioned assets if these lenders can prove that there is no other financing available on any other terms as well as showing that the originally secured party is still adequately protected in the circumstances. ${ }^{74}$ It should be noted that a priming lien has the effect altering the priorities of pre-existing secured creditors and as such the burden of proof for authorising such a lien is a heavy one. ${ }^{75}$ A prepetition lender would thus often choose to fund the debtor's post-petition operations with a DIP loan so as to avoid this 'priming fight' with another third-party post-petition lender that would seek to obtain a priming lien on the pre-petition lender's collateral. ${ }^{76}$

67 See Burchinal v Cent. Wash. Bank (In re Adams Apple, Inc.), 829 F.2d 1484, 1490-91 (9th Cir. 1987).

68 ABI 'Chapter 11 Commission Report' 23.

69 Rankin et al 'Defensive debtor-in-possession financing' presentation at 36th Annual Judge Alexander L. Paskay Seminar on Bankruptcy Law and Practice available from http://lamfin.arizona.edu/fixi/creditmod/DIPFinancing.pdf.

7011 U.S.C. S 364(a). Carmichael \& Graham Accountants' Handbook, Special Industries and Special Topics (2012) 20. Under the US Code, the debtor-in possession can obtain unsecured credit outside the ordinary course of business after notice and a hearing. See also 11 U.S.C. s 503 (b)(1).

71 11 U.S.C. s364(b) read with 11 U.S.C. s 503(b)(1).

7211 U.S.C. s 364(b) and (c).

7311 U.S.C. s $364(d)$. See also 11 U.S.C. s 361.

74 Gaur 2012 Taxmann's SEBI \& Corporate Laws Journal 23. See In re Mosello 195 B.R. 277, 289 Bankr. S.D.N.Y. 1996.

75 Rankin et al 4.

76 Zdunkewicz 2014 SRR Guest Article 1-2. 
Under the Code, the ranking of allowed claims is the same whether the insolvency proceeding is a Chapter 7 liquidation or a Chapter 11 reorganisation, except that under certain circumstances involving creditor consent, a Chapter 11 plan of reorganisation can modify the strict priority rules. The hierarchy of claims under Chapter 11 are as follows: ${ }^{77}$

(1) Allowed claims secured by liens valid under state law and unavoidable under bankruptcy law. ${ }^{78}$

(2) Next are allowed expenses and claims that have priority under the Code and in corporate insolvency cases, expenses relating to the administration of the case rank at the top of the priority claims category and are divided into three different ranks. ${ }^{79}$

(a) First are super-priority claims relating to DIP financing in Chapter 11 cases. $^{80}$

(b) Second are super-priority claims under the Code to compensate a secured creditor for the failure to provide adequate protection while the automatic stay is in effect and the trustee or debtor-in-possession uses the collateral. ${ }^{81}$

(c) Third are all other administrative expenses subject to the order of priority listed in Code. ${ }^{82}$

(3) The allowed claims of general unsecured creditors are next in the pecking order, followed by subordinated claims. Any surplus goes to equity holders.

An interesting amendment under the US Bankruptcy Abuse Prevention and Consumer Protection Act of 2005 (BAPCPA) has been made in section 503(b)(9). This section was included as part of BAPCPA to provide added protection to certain trade creditors by allowing suppliers of goods to assert an administrative expense claim for the value of goods sold and delivered to, and received by, a customer in the ordinary course of business within 20 days of the customer's bankruptcy filing (the “503(b)(9) Claim”), 83

77 See generally Gilson 'Investing in distressed situations: A market survey' ch 1 in Gilson (ed) Creating Value through Corporate Restructuring: Case Studies in Bankruptcies (2010) 64; Du Preez 27; Platt Principles of Corporate Renewal (2004) 33. See also Flaschen et al Practical Law Restructuring and Insolvency Multi-jurisdictional Guide 2014/15: Q\&A Template United States (2014) available from https://www.insol.org/_files/Fellowship \% 20Class \% 20of \% 20 2014 \% 20- \% 202015/Literature/Practical \% 20Law \% 20Restructuring \% 20\& \% 20Insolvency \% 20USA \% 20Q\&A.pdf.

78 Bankruptcy Code s 506.

79 S $507(\mathrm{a})$.

80 Pursuant to Bankruptcy Code s 364(c)(1).

81 S $507(\mathrm{~b})$

82 S 503(b). Wages for services rendered after the commencement of the bankruptcy case are first on the S 503(b) list.

83 See Nathan et al 'The 20-Day Goods Priority Claim Under Bankruptcy Code Section 503(b)(9): The Complexities of a Seemingly Simple Statute' 2009 Lowenstein Sandler 3 available from https://www.lowenstein.com/files/Pub lication/4b72f2a3-3867-45de-9457-6e5680072d0e/Presentation/Publicatio nAttachment/1 deb8129-d8f2-469e-babc-7affacc0730f/The \% 2020-Day \% 20 Good \% 20Priority \% 20Claim.pdf (accessed 2016-06-30); Gage 'Should 
These '20-day' claims are distinctive because they cannot be paid pro rata in the same way as general unsecured claims, nor can they be paid over time through a reorganisation plan, like secured claims. ${ }^{84}$ Instead all these trading claims must be paid in full in cash on the effective date of the plan. ${ }^{85}$ In essence, this section converts creditors who under the previous dispensation would have qualified only as ordinary unsecured creditors into a class that must be fully compensated before a reorganisation plan may be implemented. Consequently, so-called 20day claimants can now exercise considerable influence over Chapter 11 proceedings and their sheer numbers may ultimately have a huge impact on the success of a reorganisation plan by curbing the DIP financing market. ${ }^{86}$

Another common occurrence in the US is that of 'pre-packaged plans' or 'prepacks' where the plan and disclosure statement are prepared in advance and sufficient favourable votes are obtained prior to the commencement of the Chapter 11 case, leading to a prompt plan confirmation. ${ }^{87}$ A pre-packaged plan of reorganisation thus represents a hybrid restructuring tool, whereby a private restructuring arrangement is agreed upon and the company subsequently implements the plan through a judicial process. ${ }^{88}$ For some debtors, the filing of a bankruptcy petition is the end result of a reorganisation process rather than the beginning of such a process. The goal of the pre-packaged Chapter 11 process is to maximise the effects of a bankruptcy in a minimum amount of time, and in essence this means that the trade debt is still relatively low at the time of submission, which in turn suggests there is a higher chance of a successful turnaround. ${ }^{89}$

A pre-packaged plan is also an effective tool for dealing with so called hold-out creditors. ${ }^{90}$ If a pre-packaged plan is approved by the required percentages of creditors and stockholders, and certain other requirements are satisfied, the plan may be 'crammed down' on all parties, including parties that did not vote on or voted against the plan. ${ }^{91}$ This effectively deals with the hold-out situation as it basically removes any economic advantage to non-participation. Another advantage to such a prepack arrangement would be minimal reputational damage

Congress Repeal Bankruptcy Code Section 503(B)(9)?' 2011 ABI Law Review 217.

84 Routh 'Twenty-Day Claims: The Anticipated and Unanticipated Consequences of Code \$503(b)(9)' 2006 American Bankruptcy Institute Law Review 24 (describing twenty-day claims as a 'hybrid' of prepetition claim and administrative expense claim).

85 S $1129(\mathrm{a})(9)(\mathrm{A})$.

86 Nathan 2009 Lowenstein Sandler 3-6.

87 Bartell A Guide to the Judicial Management of Bankruptcy Mega-Cases (2007) 27.

88 Harner \& Griffin 'Facilitating Successful Failures' 2013 Florida Law Review 17.

89 Du Preez 27.

90 Brigham \& Daves Intermediate Financial Management (2012) 955.

9111 USC s $1129(b)$ 
suffered due to the shortened time frame as well as the preserving of the value of the company that would otherwise 'vanish' with the entry into the normal bankruptcy procedure.

The US DIP system is a classic example of a debtor-friendly structure that is modelled around the genuine desire to rescue those distressed businesses. ${ }^{92}$ This type of system is clearly not to the detriment of creditors and illustrates well that there is a balance that needs to be struck between both interests. Essentially the rationale behind this system is that all creditors will be better off if the debtor is successfully rescued from liquidation. 93

\section{A Concise Comparison of the Post-commencement Financing Spheres in the US and South Africa}

It is fairly obvious that both the DIP system as found in Chapter 11 in the US and the business rescue proceedings of Chapter 6 in South Africa aim to be debtor friendly, while still balancing the interests of creditors. ${ }^{94}$ The approach taken in the US is extremely sophisticated, stemming from an evolution of the laws relating to corporate rescue. The process is predictable and directed by specialist courts, and supervised by judges that specialise in the solvency and rescue arena. ${ }^{95}$ The approach in South Africa is still fairly uncertain in that the legislation is relatively new and courts are still working out the kinks in the approach. ${ }^{96}$

South Africa is struggling to establish a rescue culture due to a variety of reasons as oppose to the US where the rescue culture is fairly evident resulting from a transparent process which is highly supported by the parties involved. There is also little or no damage to a company's reputation in the US when it files for bankruptcy under Chapter 11 because the public appreciates that the system works in favour of salvaging distressed entities. ${ }^{97}$

Although both jurisdictions make provision for post-commencement financing, there are substantial differences that should be noted. A significant factor in US turnaround finance regime is the ranking of DIP lenders as a super-priority administrative claims, whereas in South African these financiers are ranked below the practitioner's remuneration, costs of the actual proceedings as well as below employee claims. Also noteworthy is the phenomenon where a priming lien under section 364(b) has the effect of altering the priorities of pre-existing lienholders.

92 Loubser 2013 SA Merc LJ 441

93 Pretorius \& Rosslyn-Smith 2014 Southern African Business Review 113-116.

94 Pretorius \& Du Preez 2013 South African Journal of Entrepreneurship and Small Business Management 172.

95 Loubser 2013 SA Merc LJ 439.

96 Pretorius \& Du Preez 2013 South African Journal of Entrepreneurship and Small Business Management 173.

97 Ibid. 


\section{International Guidelines on Insolvency Law}

\section{The World Bank}

The World Bank's international publication titled 'Principles for Effective Creditor Rights and Insolvency Systems,98 contains various recommendations regarding the principles for successful postcommencement financing. One such principle relates to the issue of stabilising distressed businesses along with the sustainment of business operations. In this principle it is stated that, subject to certain safeguards, a business should have access to commercially viable forms of funding and that these 'loans' should be on terms of agreement that afford repayment priority under exceptional circumstances in order to allow the debtor to meet its day-to-day needs. ${ }^{99}$

In developing countries (such as South Africa) the type of financing that is usually available is in the form of debt in which security is often required, taking the shape of unencumbered assets that are either immovable or movable in nature. It is of importance to note that the World Bank collaborated with UNCITRAL to develop a set of principles that would afford various jurisdictions guidance in evaluating and developing new laws which would stand up to the international standard of insolvency laws. ${ }^{100}$ It is in the light of this collaboration that this paper will focus on the UNCITRAL provisions as they are all-encompassing.

\section{UNCITRAL's Legislative Guide on Insolvency Law}

The 'Legislative Guide on Insolvency Law'101 sets out very clearly the provisions that are regarded as essential by UNCITRAL when drafting insolvency laws in any jurisdiction. ${ }^{102}$ A considerable section of this guide focuses on the matter of post-commencement finance, for obvious reasons. The guide describes the post-commencement financing needs of a debtor as well as noting the possible sources of such finance in the form of available cash, the sale of liquid assets, funding through the means of trade credit, and loans. ${ }^{103}$ Emphasis is placed on the need for new funding and thus a tentative distinction is drawn between the financing of transactions outside the normal course of business and those that can be considered necessary for survival. ${ }^{104}$

98 World Bank 'Principles for effective creditor rights and insolvency systems' revised 2015 available from http://www.worldbank.org/en/topic/ financialsector/brief/the-world-bank-principles-for-effective-insolvency-andcreditor-rights (accessed 2016-06-30).

99 Principle C9.2, World Bank 17.

100 Burdette Part 12004 SA Merc LJ 263.

101 UNCITRAL supra n 28 at 115.

102 Burdette Part 12004 SA Merc LJ 253

103 Van der Linde supra $n 43$ at 43.

104 UNCITRAL supra $\mathrm{n} 28$ at 115. 
The legislative guide contains recommendations regarding postcommencement finance provisos that should be included in present-day insolvency and creditor systems. Firstly, note is made of the purpose of having post-commencement finance provisions in business rescue legislation; these entail that for the continued operation and survival of the company, a degree of financing is required as well as provision for the correct protection of the entities that supply this type of funding. Finally it must be ensured that protection is granted to those whose rights will be affected by the issuing of such financing. ${ }^{105}$

UNCITRAL recommends specific content be included into the relevant legislation surrounding post-commencement finance. This specifically deals with the attracting and authorising of turnaround funding. Under recommendation 63 it is formulated as follows: 106

The insolvency law should facilitate and provide incentives for postcommencement finance to be obtained by the insolvency representative where the insolvency representative determines it to be necessary for the continued operation or survival of the business of the debtor or the preservation or enhancement of the value of the estate. The insolvency law may require the court to authorize or creditors to consent to the provision of post-commencement finance.

$\mathrm{Du}$ Preez mentions the fact that UNCITRAL created this recommendation based on three different aspects of postcommencement financing which includes the need for turnaround funding, the sources of such funding and the authorisation of said financing. ${ }^{107}$

In terms of the need for funding, it is clearly critical for a struggling company to have access to funding that will enable it to pay the day-today costs of business. ${ }^{108}$ The funding could come from various sources (as previously mentioned: liquid assets, incoming cash flow from operations or funding from a third party) and this need for funding should be identified early in the process in order to make sure the continuation of the business is realised after that business has filed for such proceedings. ${ }^{109}$ In terms of the sources, there are two types, namely pre-insolvency lenders who provide trade credit or in some instances provide new funds in order to increase the probability of the company surviving and in turn salvaging their initial claims, and lenders with no previous relationship to the distressed company who are motivated by the chance to receive a higher rate of return on an investment. ${ }^{110}$ The final pillar in the trio regarding recommendation 63 relates to the authorisation for post-commencement finance; UNCITRAL notes that in various jurisdictions the insolvent entity is allowed to decide

105 Idem 118, recommendations 63-68.

106 Ibid.

107 Du Preez 22-23.

108 UNCITRAL supra n 28 at 113 par 94.

109 Idem 114 par 95.

110 Idem 115 par 99. 
whether new financing is required and then subsequently is authorised to obtain unsecured credit without court approval, whereas in some dominions court approval is required in such circumstances. ${ }^{11}{ }^{1}$ For this reason UNCITRAL decided that court intervention is only really required where the priority or security derived from the post-commencement financing will affect the interests of pre-existing secured creditors who are inherently against the rescue proposal. ${ }^{112}$

The 64th recommendation relating to the priority for post commencement finance states the following: ${ }^{113}$

The insolvency law should establish the priority that may be accorded to postcommencement finance, ensuring at least the payment of the postcommencement finance provider ahead of ordinary unsecured creditors, including those unsecured creditors with administrative priority.

This recommendation is based on two considerations. The first one is in respect of expenses relating to the operation of standard business tasks. These are usually dealt with as administration expenses, and such administrative creditors will not rank ahead of secured creditors but will rank ahead of those creditors whose claims are unsecured as well as ahead of statutory priorities such as taxes. In terms of a trade creditor advancing funds to the entity, this is seen as lending funds to the insolvent estate as opposed to a distressed entity, and it is due to this that the funding becomes an expense to the insolvent estate and subsequently attracts a higher ranking. ${ }^{114}$ The second reason this recommendation came about was due to the fees of the insolvency representative or professional employed in the matter; in some jurisdictions these costs are assigned super-priority which ranks ahead of administrative creditors. ${ }^{115}$

The next three recommendations relate directly to the security that will or can be lodged in favour of the turnaround funding that is forwarded by the various sources. These recommendations are formulated as follows: ${ }^{116}$

65. The insolvency law should enable a security interest to be granted for repayment of post-commencement finance, including a security interest on an unencumbered asset, including an after-acquired asset, or a junior or lower-priority security interest on an already encumbered asset of the estate.

66. The law should specify that a security interest over the assets of the estate to secure post-commencement finance does not have priority ahead of any existing security interest over the same assets unless the insolvency representative obtains the agreement of the existing secured creditor(s) or follows the procedure in recommendation 67.

\footnotetext{
111 Idem 117 par 105.

112 Idem 117 par 106.

113 Idem 118.

114 Idem 116 par 101.

115 Idem 116 par 102.

116 Idem 119.
} 
67. The insolvency law should specify that, where the existing secured creditor does not agree, the court may authorize the creation of a security interest having priority over pre-existing security interests provided specified conditions are satisfied, including:

(a) The existing secured creditor was given the opportunity to be heard by the court;

(b) The debtor can prove that it cannot obtain the finance in any other way; and

(c) The interests of the existing secured creditor will be protected.

Once again it is important to mention the reasons why these recommendations were put forth. These suggestions were based on the following considerations. Firstly it relates to what the security will be (i.e. security can be lodged against unencumbered assets, even though in situations of financial distress these types of assets are hard to come by, or security can be lodged as 'junior security' on encumbered assets in which there is an excess value over the asset relating to an existing obligation). ${ }^{117}$ These recommendations came about because in the case of existing lenders, their pre-commencement priority relating to encumbered assets is retained unless otherwise agreed. Additionally, in certain jurisdictions, laws exist which entail that when there is new financing, that source can be ranked above existing secured creditors; but there is often reluctance from the courts on this issue and it is usually only accepted as a final resort. ${ }^{118}$

The final recommendation relating to post-commencement financing issued by UNCITRAL deals with the effect of conversion on postcommencement finance. Under the 68th recommendation this is stated as follows: ${ }^{119}$

The insolvency law should specify that where reorganization proceedings are converted to liquidation, any priority accorded to post-commencement finance in the reorganization should continue to be recognized in the liquidation.

This was based on the fact that once a company enters liquidation proceedings, the most desirable approach is to make sure those creditors who have acquired a priority for new financing that are preliquidation, will maintain such a priority in any subsequent liquidation. The reason for this is that if this principle does not apply then there is no incentive for investment by potential financiers. ${ }^{120}$

The guidelines set down by UNCITRAL take into account the acute needs of a corporate rescue system in which there is room for successful post-commencement financing of struggling businesses. These guidelines had to be taken into account when developing a new set of corporate rescue laws in South Africa, and as a result our local rules

117 Idem 116 par 103.

118 Idem 116 par 104.

119 Idem 119.

120 Idem 118 par 107. 
largely comply with what was recommended in these guidelines. ${ }^{121}$ It must be noted that in complying, another formidable barrier against the interests of foreign investors has been lowered, and the socioeconomic impact of these laws has had and will continue to have a beneficial effect on all affected persons. ${ }^{122}$

\section{Conclusion and Recommendations}

A point that is evident from the comparison made between the South African system and the US 'debtor in possession' system has to do with the ranking of creditors. In our local legislation, post-commencement financing does not take the form of a 'super-priority' status when looking at debt repayment by the borrowing entity, ${ }^{123}$ as can be seen from the list of rankings mentioned earlier. It is submitted that it may be necessary to revisit the ranking of post-commencement finance claims in an attempt to create a balance between the rights of employees and highpriority claims. ${ }^{124}$ It is surmised that this will only come about if the necessary political will is generated in order to create an environment in which high-level negotiations between various stakeholders such as labour unions and policy makers could take place.

Along with this point, the debate about whether or not secured creditors (pre-business rescue) rank higher than all secured postcommencement finance claims under section 135(3)(a)(i) should also be considered. In order for light to be shed on this uncertain area, law and policymakers will have to address the ranking of claims in order for investors and financial institutions to be able to take informed decisions.

A significant issue that seems to have emerged as well is the tendency shown by companies in times of struggle to abuse the new legislation:

Anecdotal evidence (confirmed by the facts in the many failed applications to court for business rescue orders) strongly suggests that there is widespread abuse of the voluntary business rescue proceedings in terms of section 129 of the Companies Act 2008 by company directors, with the assistance of unethical business rescue practitioners. ${ }^{125}$

121 Burdette 'Some initial thoughts on the development of a modern and effective business rescue model for South Africa (Part 2)' 2004 SA Merc LJ 446.

122 Idem 447.

123 Du Preez 155.

124 Bradstreet 2011 SALJ 359. According to Bradstreet, the reason that these employee claims are ranked highly is due to the fact that if these claims were ranked lower, businesses could suffer a fatal blow in the form of multiple resignations by employees who have lost faith in the company. Bradstreet states that by offering this high-priority claim, employees will have the desired motivation to stay and continue their employment as opposed to cutting their losses and looking for alternative employment.

125 Loubser 2013 SA Merc LJ 456. 
Such 'abuse' can either be attributed to the legal and financial advisors giving the company incorrect advice, or to the devious need to make unwarranted use of the creditor moratorium that is imposed. ${ }^{126}$ Either way, this plays a major role in corroding the trust of potential investors. ${ }^{127}$

As can be seen from what has been discussed so far, one of the main reasons that there seems to be a lack of post-commencement finance in South Africa has to do with the fact that the legislation is underdeveloped. Judicial management did not match up to current predispositions regarding insolvency law due to an undue preference for the interests of the creditors. ${ }^{128}$ According to various authors this main characteristic of the system, namely that it was deemed to be 'creditor friendly' also attributed to the failure of that system. ${ }^{129}$ South Africa's new Chapter 6 provisions are considered to be 'debtor friendly' as they balance the rights of both the debtor and the creditors. ${ }^{130}$ The problem is that due to having had a creditor-friendly regime in this country for so long, a sudden 180-degree change to a debtor-friendly system is not necessarily going to show positive effects immediately.

There are a currently strong demand for a more robust private equity industry in South Africa that not only invests in businesses requiring commercial and financial restructuring but also invests in distressed businesses too. However, it needs to be understood that creating an investment culture that is pro-business rescue among the corporate landscape in South Africa is not going to happen overnight. One of the claims which arise from the legal origins literature is sometimes referred to as the 'quality of law' statement which according to La Porta: ${ }^{131}$

claims that legal rules shape economic outcomes according to how far they support market-based economic activity as suggested in new institutional economics. It is argued that legal protection of the interests of the shareholders and creditors will increase the flow of investments and enhance the availability of external finance to firms.

In conclusion, one of the conceptual challenges when assessing any legislative process is determining what the measures of success should look like. It is submitted that without accurate and reliable statistics based on international best practice, we have very little foundation for decision-making or improvement.

126 Du Preez 154

127 Pretorius \& Du Preez 2013 South African Journal of Entrepreneurship and Small Business Management 185.

128 Bradstreet 2011 SALJ 354.

129 Loubser 'Judicial management as a business rescue procedure in South African corporate law' 2004 SA Merc LJ 162.

130 Bradstreet 2011 SALJ 357.

131 La Porta et al 'The Economic Consequences of Legal Origins' 2008 Journal Economic Literature 285-332. See also North Institutions, Institutional Change, and Economic Performance (1990) for a broad discussion on this topic. 
The newly introduced corporate rescue regime has yet to provide us with results that leave us with a sense of accomplishment. The shift away from judicial management was much needed as became clear from the international legislative directives on insolvency law. The contents of Chapter 6 have now potentially placed companies that are in financial distress in a potentially better position with regard to the options available to them. However, in order for the potential turnaround of a struggling entity to become a reality, a degree of financial support is needed in order to satisfy the day-to-day costs of business as well as the long-terms costs of the proceedings. ${ }^{132}$ What is evident is that local legislation loosely adheres to the international guidelines relating to the corporate rescue realm but due to the novel approach of Chapter 6, success in this area has not met expectations. The proposition of providing post-commencement finance should be made attractive to investors with the right risk profile. However, it is concluded that any reform effort should only come about as part of a holistic approach to deal with shortcomings in the Act.

132 Van der Linde supra $\mathrm{n} 43$ at 41. 